\begin{abstract}
В середині виробничих приміщень можуть утворюватися вибухонебезпечні концентраціі різних речовин. За наявності достатнъої кількості кисню та джерела запалення така ситуащія закінчується вибухом, який може призвести до руйнування будівельних конструкцій та будівлі в цілому. 3 метою захисту промислових будинків від можливих руйнувань внаслідок вибуху усередині приміщення здійснюють змічнення й посилення стійкості несучих конструкцій.
\end{abstract}

Одним із дієвих способів захисту будівельних конструкції від надлишкового тиску вибуху є застосування легкоскидних конструкцій. 3 метою розв'язання практичних завдань вибухозахисту промислових будинків і споруд необхідно однаковою мірою вміти підібрати площу та параметри легко скидних конструкцій. Крім того, для зниження виникаючих навантажень до безпечних величин необхідно правильно розрахувати несуиі конструкції на динамічну стійкість при збереженні їх несучої здатності. Поставлена задача забезпечення захисту проти вибуху за допомогою безінерційних легкоскидних конструкцій із гнучкими елементами може бути вирішена иляхом комплексного врахування механічних властивостей стільникових полікарбонатних листів.

Проведені експериментальні дослідження поведінки безінериійних легкоскидних конструкцій із гнучкими огороджувальними елементами під впливом динамічних навантажень в умовах вибуху. На основі отриманих результатів визначено ефективну жорсткість та критичне переміщення стільникових полікарбонатних листів гнуиких елементів. Встановлено, що для стільникових полікарбонатних листів товщиною 4-8 мм ефективна жорсткість лежить у межах 301-215 Н·м при ивому критичне перемімення країв становитиме 2,9-9,8 мм.

Запропоновано математичну модель, що враховує вплив геометричних розмірів та критичного значення прогину полікарбонатного листа, як гнучкого елементу огородження, на умови спрацюовання легкоскидних конструкцій

Ключові слова: легкоскидні конструкціi, полікарбонатний стільниковий лист, ефективні механічні характеристики, експериментально-розрахунковий метод
UDC 614.839

DOI: $10.15587 / 1-4061.2020 .192680$

\section{REVEALING PATTERNS OF THE EFFECTIVE MECHANICAL CHARACTERISTICS OF CELLULAR SHEET POLYCARBONATE FOR EXPLOSION VENTING PANELS}

S. Pozdieie v

Doctor of Technical Sciences, Professor, Chief Researcher** E-mail:svp_chipbbk@ukr.net

K. My hale nko

PhD, Associate Professor*

E-mail: migalenkok@ukr.net

V. Nuianzin

$\mathrm{PhD}$

Department of Physico-Chemical Bases of Development and Extinguishing of Fires** E-mail: Nuyanzin@gmail.com

0. Z e m I i a n s y i

$\mathrm{PhD}$, Associate professor*

E-mail: omzem1@gmail.com

T. Kostenko

Doctor of Technical Sciences, Professor

Department of Construction

Objects Safety and Labor Protection**

E-mail: Tatiana.kostenko@gmail.com

*Department of Automatic Safety Systems and Electrical Installations**

**Cherkasy Institute of Fire Safety named after Chornobyl Heroes of National University of Civil Defense of Ukraine Onoprienka str., 8, Cherkasy, Ukraine, 18034

\section{Introduction}

Statistical data $[1,2]$ show that each thousand of fires includes two cases that are accompanied by explosion $(0.2 \%)$. For every hundred fires in the industrial sector, one fire is accompanied by explosion $(1.0 \%)$. When a fire is accompanied by explosion the level of socio-economic losses amounts to the largest values. Such a situation tends to aggravate given the density of explosive production facilities. This is most important in the fields of energy, fuel processing, fuel-saving, for chemical enterprises, as well as enterprises in the agroindustrial, food, and woodworking sectors [3].

For industrial premises where there is a risk of explosions of combustible mixtures, along with measures to prevent them, the measures are taken to protect people, equipment, and building structures in the event of an explosion inside the premises. Such a situation is predetermined by the fact that the accumulation of explosive concentrations happens so fast that the attending staff are usually unable to prevent the explosion. 
The higher speed of flame propagation and the elevated temperature created during an explosion of combustible mixes inside premises lead to a sharp increase in the pressure inside a building, to destruction of elements of equipment and building structures, to terminating production. The main damage to industrial production is caused by the collapse of building structures. Accidents are accompanied by injuries to both the attendants and the rescue workers' units [4].

Providing for conditions, which in case of explosion would prevent destruction of elements of building structures, is the necessary condition for reducing traumatism and material losses. Effective way to protect building structures against the excessive pressure of explosion is to use explosion venting panels, whose role can belong to glazed windows.

Among the modern varieties in windows are polycarbonate windows. Compared with conventional varieties, these windows are made from polycarbonate, which is capable of keeping the heat at a high level, thereby perfectly resisting even the most significant temperature changes, and it is resistant against various injuries. Many experts advise using polycarbonate windows inside premises where it is necessary to improve the level of sound insulation and increase the amount of penetrating light.

In fact, such an article most often consists of a plastic, metallic, metal-plastic, in rare cases wooden, frame and the cellular or monolithic polycarbonate inserted into it. Such a window is very similar to a standard one, with polycarbonate instead of glass. As regards residential premises, polycarbonate windows have been used quite recently. These windows in most cases do not open. Their application is for decorative purposes.

Polycarbonate has the same transparency as glass. In terms of weight, strength, and safety characteristics, monolithic polycarbonate outperforms conventional glass. Windows from polycarbonate are made using the principle of a double-glazed window; they can open. The only drawback of such windows is their price. Monolithic polycarbonate for windows is made by a special technology, which implies a high degree of polycarbonate purification from all sorts of impurities, which gives the material the maximum transparency; given this, its price is significantly higher than that of the standard polycarbonate.

The undeniable advantages of polycarbonate windows are that their application makes it possible to provide more comfort to premises. However, at the same time, it is worth noting that not every manufacturer of these types of windows can ensure the high quality of its products.

Promising for the production of EVPs are window systems from cellular polycarbonate sheets, whose physical appearance is shown in Fig. 1. $a$

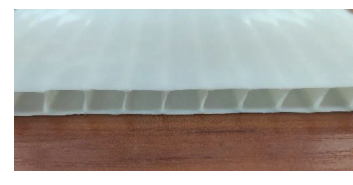

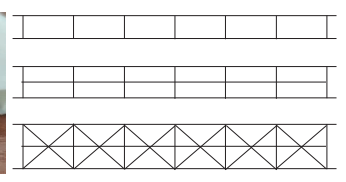

$b$
4-10 mm

$16 \mathrm{~mm}$

$25 \mathrm{~mm}$

Fig. 1. Structure of cellular polycarbonate sheets:

$a$ - physical appearance; $b$ - design features of sheets of different thicknesses

Using a given material would allow multiple application of flexible fencing elements, and could reduce labor and material costs for assembly and installation.
Modern construction industry exploits various building materials that can be used as explosion venting panels; peculiarities of their application, however, have not been investigated in detail. These materials include polycarbonate cellular sheets. Thus, it is a relevant task to study features of using polycarbonate cellular sheets for explosion venting panels.

\section{Literature review and problem statement}

One of the main tasks related to the general issue of explosion danger is the ability to determine occurring loads, operating on the elements of structures during explosion of combustible gas-, steam- and air-dust mixtures indoors. The current theory of burning, explosion, and detonation of combustible mixtures properly describes processes associated with the phenomena of explosive combustion during their progress inside pipes and other similar spaces. Paper [5] considered analytical and numerical methods for predicting the internal and external pressure of gas-air mixtures explosion within large volumes; however, explosions of combustible mixtures within larger volumes, in comparison with volumes at industrial premises, have not been examined enough up to now. Given this, resolving practical tasks for protection of premises with explosive industrial production against destruction requires that such initial data should be considered that would make it possible to obtain reliable results in terms of protection against explosions.

The main idea of protecting industrial premises in the event of explosion of combustible mixtures indoors is to ensure the strength and durability of bearing structures. The use of specialized steel structures and high-strength concrete reinforced with fibers was considered in paper [6]. Perforated plates were studied as a means to weaken an explosive wave in $[7,8]$. Such approaches make it possible to reduce loading that results from explosion. Work [9] gives an overview of methods to design and modernize structural elements in order to minimize effects of explosion. The methods under consideration do not make it possible to reduce the explosion pressure throughout the entire premises. They should be used to improve the strength and plasticity of building structures, as well as to reduce the number and size of debris that fly around during explosion.

Another approach is to break down or open specialized explosion venting panels (EVPs) at minimal loads (pulse, pressure) $[10,11]$. However, solving practical tasks related to protection of premises and structures against explosion requires the ability to choose the area and parameters for EVPs and to correctly calculate supporting structures for dynamic stability, while retaining their carrying capacity. To this end, one has to determine loads occurring during the explosion of combustible mixtures indoors.

A mathematical model for assessing the maximum values of excessive pressure during explosions of hydrogen and hydrocarbons was considered in paper [12]. The proposed model accounts for the geometry of a site and the characteristics of exploding hydrocarbons. However, no features of EVP construction were considered by the authors.

Paper [13] reported using numerical modelling to consider an explosion of hydrogen-air environment in premises. The impact of EVP dimensions on explosion temperature, excessive pressure, air flow velocity was analyzed. Other factors affecting the processes that occur during explosions within certain volumes were explored in work [14]. In par- 
ticular, the authors analyzed impact of EVP opening time on explosion characteristics. It was established that inside the premises the maximum pressure values and its reduction time demonstrate a linear dependence on opening time. However, design features of EVP construction were not investigated.

Response of rectangular thin plates, undergoing large deflections during explosion, was investigated in work [15]. However, the results obtained cannot be used for constructing EVP, based on cellular polycarbonate, capable of exiting locks, because the authors studies plates with fixed, clamped edges.

Summing the above, we can conclude that most scientific research is aimed at improving the stability of building structures to the negative effects of an explosion. The issue of using modern materials for explosion venting panels was not studied enough. In addition, there are no complete studies on the use of CPS as an element of explosion venting panels.

On the other hand, when it comes to practical application, there is a need to devise scientifically reasonable approaches to the design of explosion venting panels with CPS. Therefore, it is a relevant task to define structural features of EVP with CPS. High reliability and independence of EVP opening are the main requirements that should be satisfied when choosing their design parameters.

\section{The aim and objectives of the study}

The aim of this study is to reveal patterns of enabling inertia-free explosion venting panels with flexible enclosing elements depending on their design parameters during explosion under the influence of dynamic loads.

To accomplish the aim, the following tasks have been set:

- to devise a procedure and to conduct an experimental study into performance of the inertia-free explosion venting panels with flexible enclosing elements under the influence of dynamic loads during explosion;

- based on our experimental study, define effective parameters for deforming cellular polycarbonate sheets of flexible elements;

- using the derived effective characteristics of deforming cellular polycarbonate sheets of flexible elements, investigate the conditions for their release from the locks of a standard window profile of explosion venting panels arranged on their base.

\section{Procedure for investigating performance of inertia-free explosion venting panels with flexible enclosing elements}

The main idea when testing CPSs for determining their effective rigidity is the application of distributed load to CPS in a frame made from a window PVC profile of the most common sizes in the manufacture of EVP systems, imitating the influence of excessive pressure of explosion. That is, one should test actual samples whose dimensions are equal, or close to the size of actual elements in EVP systems. At the same time, one should measure the force and deformation indicators of CPSs fixed in the frames in the same way as in actual EVP systems.

To perform such tests, we used an experimental installation, consisting of a fixing frame, a loading node, and measurement infrastructure (Fig. 2).

Fig. 2 shows the measurement procedure in the testing installation and the layout of a steel plate on CPS, installed in the frame made from a PVC window profile.

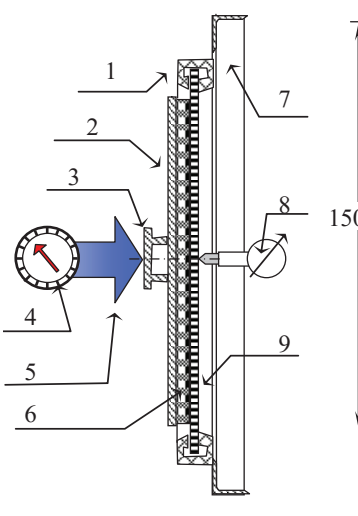

$a$

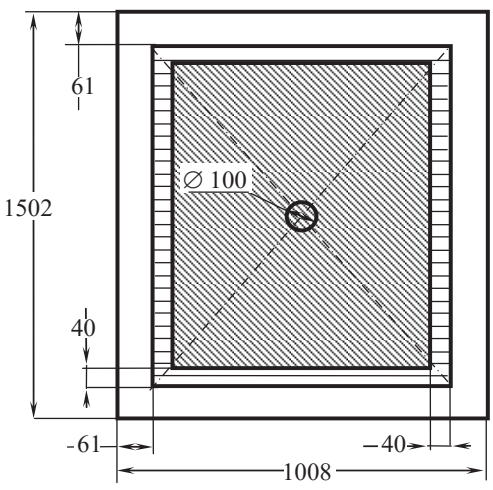

Fig. 2. Schematic of installation for testing cellular polycarbonate sheets for the effects of excessive pressure during explosion: $a-$ measurement procedure in the testing installation: 1 - frame of EVP element, 2 - steel sheet, 3 - loading bracket, 4 - dynamometer, 5 - load, 6 - layer of mineral wool, 7 - supporting frame, 8 - clock type indicator, 9 - cellular polycarbonate sheet; $b$ - layout of a steel plate on CPS

During testing, the frames hosted fixed CPS of thickness $4 \mathrm{~mm}, 6 \mathrm{~mm}, 8 \mathrm{~mm}$. CPSs of the same thickness were tested twice.

Samples of window frames made from a PVC profile were loaded with a horizontal loading. Horizontal loading was applied through a distribution system.

Window frames made from a PVC profile with an assembled cellular polycarbonate sheet of thickness $4 \mathrm{~mm}, 6 \mathrm{~mm}$ and $8 \mathrm{~mm}$ are loaded by a hand winch. Loading is measured by using the dynamometer DPU-0,5-2. To measure the deformations, we applied the clock type deflection meter $6 \mathrm{PAO}$ with a step of $0.01 \mathrm{~mm}$, which was installed in the geometric center of a polycarbonate sheet (Fig. 2).

CPSs in the frames made from a PVC window profile are tested in the following sequence. The frame hosts a CPS of $4 \mathrm{~mm}$ thick, as shown in Fig. 2, fixed by pins. A force winch applies an effort to a loading cylindrical bracket. By applying the effort in a stepwise fashion, we measured its magnitude by the dynamometer DPU-0,5-2, and the magnitude of maximum deflection by the clock type deflection meter 6PAO. The test ends when one notices signs of CPS edges being released from a node that fastens the frames. At this time point we registered the applied load and maximum deformation at the time the edges of CPS were released from the fastening nodes. The frames then host another fixed CPS with the same thickness, and the experiment is repeated in the same sequence once more. The same two tests should be repeated for CPS samples with a thickness of $6 \mathrm{~mm}$ and $8 \mathrm{~mm}$.

The required data must be determined from experimental research. In order to perform an experimental study, we devised a procedure based on the common principles for measuring a wind load on window systems, described in the standards DSTU B V.2.6-89:2009 and DSTU B V.2.6-15:2011 acting in Ukraine.

The main idea of CPS testing in order to experimentally determine the distributed friction forces that hold cellular polycarbonate sheets at fastening nodes is to perform tests under a gradual application of force to the CPS fixed in the frame's element until the CPS edge leaves a fastening node. In this case, a magnitude of the registered effort is considered 
to be the magnitude of the friction force that keeps the CPS edges within the fastening nodes.

To carry out these tests, we used an experimental installation, consisting of a fixing frame, a loading node, and measurement infrastructure (Table 1).

Fig. 3 shows measurement procedures in the testing installation.
CPS within fastening nodes is performed in the following sequence. The frame hosts a fragment of the frame with a sample of CPS of thickness of $4 \mathrm{~mm}$ and dimensions of $50 \times 50 \mathrm{~mm}$, fixed by pins, as shown in Fig. 3 . A force winch, when displaced, applies an effort to the edge of a CPS sample (Fig. 3, b). By applying the effort in a stepwise fashion, we measured its magnitude by the dynamometer DPU-0,5-2.

The test ends when one observes signs that

Table 1 the CPS edges leave the fastening nodes. That moment marks the registration of the applied load at the time when the edges of CPS leave the fastening nodes. After that, a CPS of the same thickness and size is fixed in the frames and the experiment is repeated in the same sequence once more. The same two tests should be repeated for CPS samples with a thickness of $4 \mathrm{~mm}$ and dimensions of $75 \times 75 \mathrm{~mm}$. Similar tests are repeated for the $6 \mathrm{~mm}$ and $8 \mathrm{~mm}$ samples of dimensions $50 \times 50 \mathrm{~mm}$ and $75 \times 75 \mathrm{~mm}$.
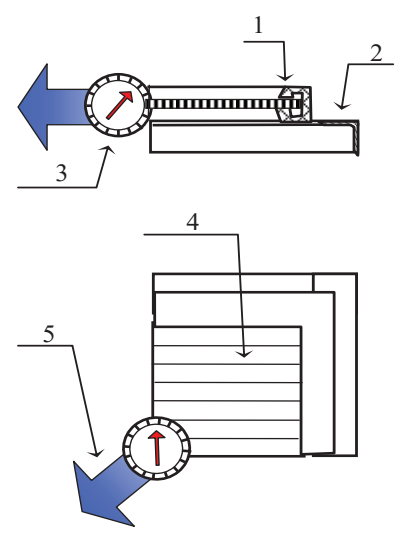

Fig. 3. Structural diagrams:

$a$ - installation for testing cellular polycarbonate sheets for the distributed forces of friction: 1 - fragment of an EVP frame's element, 2 - supporting frame, 3 - dynamometer, 4 - fragment of a cellular polycarbonate sheet, 5 - load; $b$ - sample for testing cellular polycarbonate sheets for the impact of excessive pressure during explosion

We determined the capacity to hold a polycarbonate sheet by pins at corner joints the size of $200 \times 200 \mathrm{~mm}$ with a pin, $36 \mathrm{~mm}$ thick and $114 \mathrm{~mm}$ long. The effort to pull a polycarbonate sheet was applied at an angle of $45^{\circ}$ to the profile of the corner joint in the frame's plane.

We determined a pulling force for samples of a polycarbonate sheet with a total gripping length of $100 \mathrm{~mm}(50 \times 50 \mathrm{~mm})$ and $150 \mathrm{~mm}(75 \times 75 \mathrm{~mm})$.

The samples of window frames made from a PVC profile were loaded with a horizontal loading. Horizontal loading was applied through a distribution system. Window frames made from a PVC profile with an assembled cellular polycarbonate sheet of thickness $4 \mathrm{~mm}, 6 \mathrm{~mm}$ and $8 \mathrm{~mm}$ are loaded by a hand winch. Load is measured by the dynamometer DPU-0,5-2.

Testing CPS in the fragments of frames made from a PVC window profile for experimental determination of the distributed friction forces that keep

\section{Experimental study into performance of inertia-free} explosion venting panels with flexible enclosing elements

The result of our tests is the data acquired on the deformation of CPS in frames made from a PVC window profile. The obtained data are given in Table 2 .

Our analysis of the data given in Table 2 reveals that the tests were carried out properly as the data obtained from different tests of identical samples accepted similar values. This pattern is observed both for sample deformation data and data on strength performance when we observed the CPS edges leaving fastening nodes of the $\mathrm{PVC}$ of a window profile.

Fig. 4 shows the charts of dependences of the deformation of deflection of the median CPS point on the load applied to the bracket of the force node.

Our analysis of results in Fig. 4 also reveals sufficient quality of the experimental data, since the discrepancy among them for the case of identical experiments is insignificant.

An important feature of the charts is that the resulting curves reproduce a linear dependence. This means that the deformation of CPS right up to the moment their edges leave the fastening nodes occurs in the region obeying the Hook's law and a mathematical notation of the processes of CPS deformation could employ the basic mathematical apparatus from the theory of elasticity of plates and shells. It can also be noted that the experiment confirms the possibility of using CPS as an element of EVPs, which are enabled by a CPS edge leaving a fastening node.

Table 2

Data on the deformation and strength characteristics of cellular polycarbonate sheets at a moment their edges leave fastening nodes

\begin{tabular}{|c|c|c|c|c|c|}
\hline \multirow{2}{*}{$\begin{array}{c}\text { Sample } \\
\text { No. }\end{array}$} & $\begin{array}{c}\text { CPS } \\
\text { width, } \\
\mathrm{mm}\end{array}$ & \multirow{2}{*}{$\begin{array}{c}\text { CPS } \\
\text { area, } \mathrm{m}^{2}\end{array}$} & $\begin{array}{c}\text { Maximal } \\
\text { deformation, } \\
\mathrm{mm} / \mathrm{kgf}\end{array}$ & per fragment, kgf (N) & $\mathrm{kgf} / \mathrm{m}^{2}(\mathrm{~Pa})$ \\
\hline 1 & 4.00 & 1.285 & $7.58 / 50.00$ & $75.00(735.75)$ & $58.37(572.57)$ \\
\hline 2 & 4.00 & 1.285 & $6.55 / 50.00$ & $72.00(706.32)$ & $56.03(549.67)$ \\
\hline 3 & 6.00 & 1.285 & $23.64 / 155.00$ & $184.00(1,805.04)$ & $143.19(1,404.70)$ \\
\hline 4 & 6.00 & 1.285 & $23.82 / 155.00$ & $190.00(1,863.9)$ & $147.86(1,450.51)$ \\
\hline 5 & 8.00 & 1.285 & $31.05 / 185.00$ & $225.00(2,207.25)$ & $175.10(1,717.70)$ \\
\hline 6 & 8.00 & 1.285 & $30.83 / 185.00$ & $220.00(2,158.2)$ & $171.21(1,679.53)$ \\
\hline
\end{tabular}



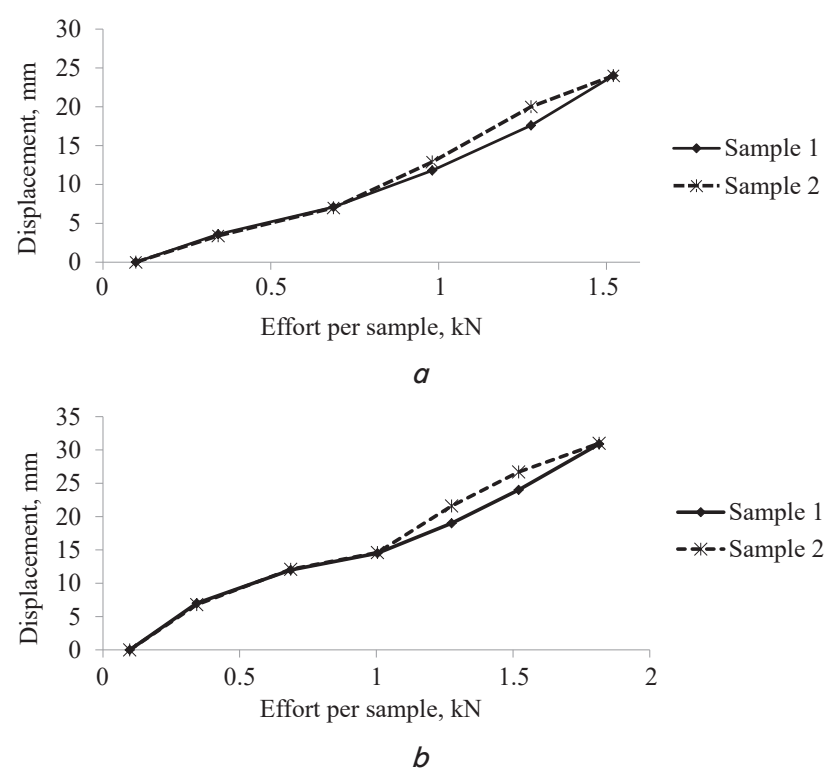

Fig. 4. Charts of displacement dependence on load for samples with polycarbonate sheets of thickness: $a-6 \mathrm{~mm} ; b-8 \mathrm{~mm}$

Fig. 5 shows charts of the derived dependences of mathematical expectation and an absolute experimental error of deforming the deflection $w_{C}$ of the median point of CPS depending on the applied load $P$, derived in the course of our experiment.

Charts in Fig. 5 confirm validity of the introduction of a hypothesis about linearity and elasticity of deformation depending on the applied force and prove that the result of experiments conducted is the reliable data.

Results from tests of corner joints with polycarbonate sheets, 4,6 , and $8 \mathrm{~mm}$ thick, are given in Table 3 .

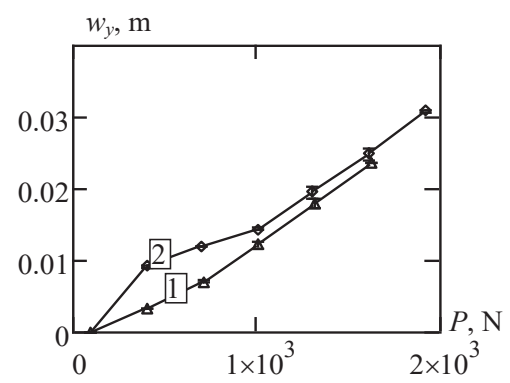

Fig. 5. Charts of mathematical expectation and absolute experimental error of maximum deflection of cellular polycarbonate sheets of different thickness depending on the applied load: 1 - thickness $6 \mathrm{~mm} ; 2$ - thickness $8 \mathrm{~mm}$

Table 3

Results from determining the forces that keep cellular polycarbonate sheets in the frames' fastening nodes

\begin{tabular}{|c|c|c|c|}
\hline \multirow{2}{*}{$\begin{array}{c}\text { Sample } \\
\text { No. }\end{array}$} & \multirow{2}{*}{$\begin{array}{c}\text { Polycarbonate } \\
\text { thickness, } \mathrm{mm}\end{array}$} & \multicolumn{2}{|c|}{ Pulling effort, kgf (N) } \\
\cline { 3 - 4 } & 4.00 & $3.75(36.79)$ & $4.6(45.13)$ \\
\hline 1 & 4.00 & $3.75(36.79)$ & $4.7(46.11)$ \\
\hline 2 & 6.00 & $7.5(73.58)$ & $8.2(80.44)$ \\
\hline 3 & 6.00 & $7.5(73.58)$ & $8.1(79.46)$ \\
\hline 4 & 8.00 & $11.5(112.82)$ & $14.2(139.3)$ \\
\hline 5 & 8.00 & $11.8(115.76)$ & $14.5(142.25)$ \\
\hline 6 & & &
\end{tabular}

Determining the effective rigidity of CPS holding CPS in the frames' fastening nodes involves estimated procedures shown in Fig. 6, 7 [11].

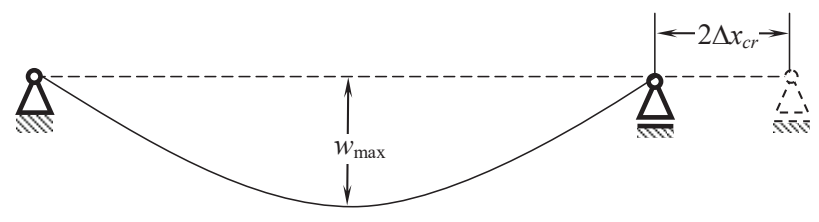

Fig. 6. Estimation procedure for the deformation of a cellular polycarbonate sheet in a frame made from a window profile used to determine the critical displacement of its end

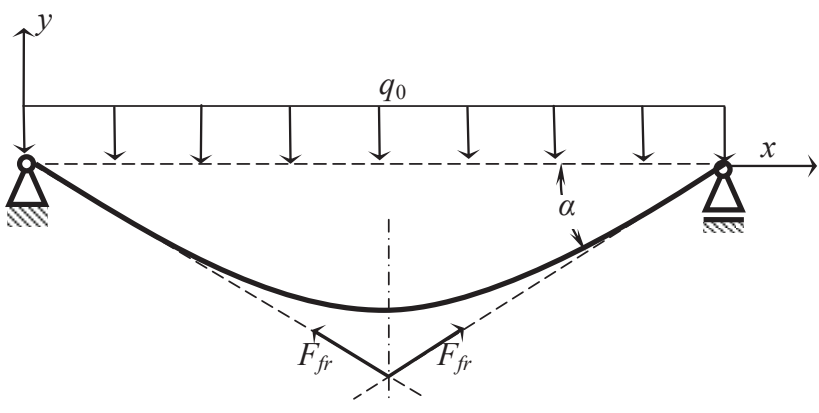

Fig. 7. Estimation procedure of force interaction in a cellular polycarbonate sheet in the frame made of a window profile exposed to excessive pressure during explosion considering friction forces at fastening nodes

Given the conditions for load application during the experiment (Fig. 2), we built an estimation scheme of load application, shown in Fig. 8.

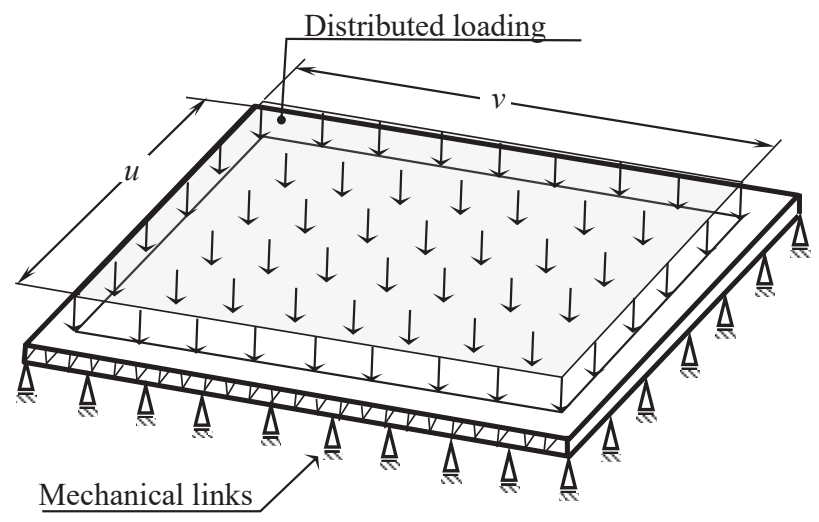

Fig. 8. Estimation scheme of load application in the experimental installation

\section{Determining effective characteristics of CPS} deformation and the conditions to leave locks

To determine such estimation characteristics as effective rigidity and effective critical displacement of CPS edges, we must construct an equilibrium equation by using equation [11]:

$$
\sum Y_{i}=q_{0} \cdot a \cdot b-2\left(F_{f r}^{x} \sin \alpha+F_{f r}^{z} \sin \beta\right)-Q_{y}=0,
$$

where $q_{0}$ is the excessive pressure of explosion, $\mathrm{Pa} ; a$ is the smallest size of a frame's opening, $\mathrm{m} ; b$ is the largest size of 
a frame's opening, $\mathrm{m} ; F_{f r}^{x}, F_{f r}^{z}$ are the friction forces holding the CPS ends in a fastening node along the $x$ axis and the $z$ axis, respectively, $\mathrm{N} ; \alpha, \beta$ are the incident angles of tangents to an elastic fold line of CPS, from the largest and smallest sides of the cross-section of the frame of an EVP system's element, respectively, rad.; $Q_{y}$ is the transverse force at a point at the intersection of diagonals of the cross-section of the frame in a section within the EVP system, $\mathrm{N}$.

In this case, the estimation scheme, shown in Fig. 7, predetermines another record to determine the resistance force of CPS through the elastic internal ones:

$$
\begin{aligned}
& Q_{y}=\frac{w_{\max } \pi^{6} D \cdot u \cdot v}{16} \times \\
& \times\left[\sum_{m=1}^{\infty} \sum_{n=1}^{\infty} \frac{\sin ^{2} \frac{m \pi}{2} \sin ^{2} \frac{n \pi}{2} \sin \frac{m \pi u}{2 a} \sin \frac{n \pi v}{2 b}}{m \cdot n \cdot\left(\frac{m^{2}}{a^{2}}+\frac{n^{2}}{b^{2}}\right)^{2}}\right]^{-1},
\end{aligned}
$$

where $u=806 \mathrm{~mm}, v=1,300 \mathrm{~mm}$, the smallest and largest sizes of the distributed load applied to CPS, respectively, in a given case coincide with dimensions of the loading plate from the testing installation (Fig. 2).

For a particular case, at the specific values of maximum deflection and its corresponding value of applied force, the equilibrium equation is recorded, according to Fig. 7,8, which takes the following form:

$$
P_{i}-\frac{w_{i \max } \pi^{6} u v D}{16 \cdot \Omega}-2 q_{f r} \Theta_{i}=0,
$$

where multipliers $\Omega$ and $\Theta$ are determined from expressions:

$$
\begin{aligned}
& \Omega=\sum_{m=1}^{\infty} \sum_{n=1}^{\infty} \frac{\sin ^{2} \frac{m \pi}{2} \sin ^{2} \frac{n \pi}{2} \sin \frac{m \pi u}{2 a} \sin \frac{n \pi v}{2 b}}{m \cdot n \cdot\left(\frac{m^{2}}{a^{2}}+\frac{n^{2}}{b^{2}}\right)^{2}}, \\
& \Theta_{i}=\frac{b \pi \omega_{\text {max }}}{\sqrt{a^{2}+\pi^{2} w_{i \max }^{2}}}+\frac{a \pi w_{\text {max }}}{\sqrt{b^{2}+\pi^{2} w_{i \max }^{2}}} .
\end{aligned}
$$

All quantities are numerical parameters, and effective characteristics $D$ and $q_{f r}$, which must be determined, are included in the equation for determining the parameters of the stressed-deformed state of CPS as linear characteristics. To define them, one can construct a system of two linear equations by using the acquired experimental data. Based on experimental data, for CPS with a thickness of $4 \mathrm{~mm}$ one can build two equations at best. For CPS of $6 \mathrm{~mm}$ and $8 \mathrm{~mm}$, based on the experimental data, it is possible to construct 6 and 7 equations, corresponding to the number of experimental points shown in Fig. 4.
Before the CPS edges are released, the restraint force in a fastening node restrains their displacement. When friction forces reach the critical value, the CPS edges start moving, which leads to their leaving a fastening node.

To determine effective rigidity of the system by transforming expression (2) the expression below was recorded:

$$
D=\frac{16 \Omega\left(P_{c r}-2 q_{f r} \Theta_{c r}\right)}{w_{c r \max } u v \pi^{6}},
$$

where $q_{f r}$ is the maximum restraining force of friction that is determined experimentally (Table 2); $P_{c r}$ is the critical force to release the edges of CPS from a fastening node, determined experimentally (Table 2); $\Theta_{c r}$ is the parameter that is defined based on the critical value of deflection $w_{c r \text { max }}$ when using the expression:

$$
\Theta_{c r}=\frac{b \pi w_{c r \max }}{\sqrt{a^{2}+\pi^{2} w_{c r \max }^{2}}}+\frac{a \pi w_{c r \max }}{\sqrt{b^{2}+\pi^{2} w_{c r \max }^{2}}} .
$$

The critical value of deflection is determined by a linear extrapolation based on dependences of the maximum deflection on applied load, the charts of which are shown in Fig. 7, 8. The extrapolation path is shown in Fig. 9.

When using formulae (5) and (6), it is necessary to define basic geometric and estimation parameters. These parameters were determined for all types of CPS. Parameters defined in order to implement formulae (5) and (6) are given in Table 4.

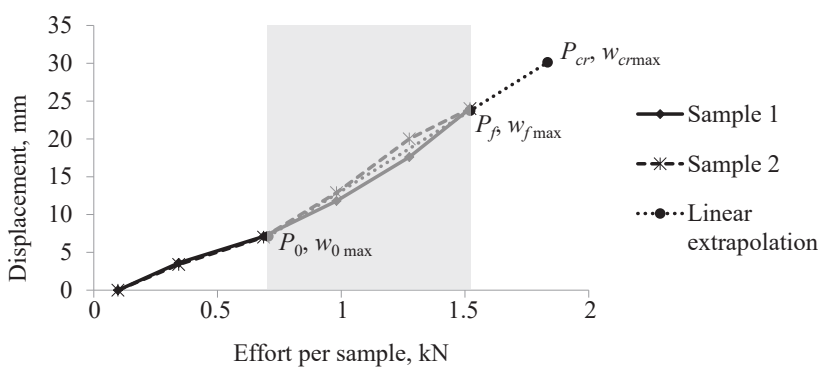

a

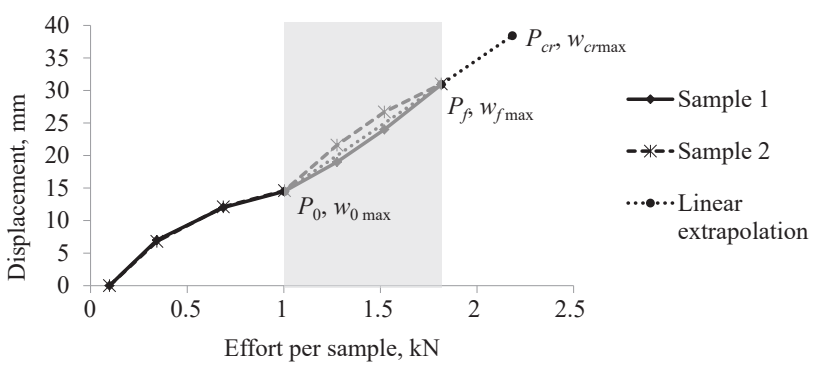

\begin{tabular}{|c|c|c|c|c|c|c|c|c|c|c|c|c|c|}
\hline \multirow{2}{*}{$\begin{array}{c}\text { CPS } \\
\text { thickness, } \\
h, \mathrm{~mm}\end{array}$} & \multicolumn{13}{|c|}{ Parameter } \\
\hline & $a, \mathrm{~mm}$ & $b, \mathrm{~mm}$ & $u, \mathrm{~mm}$ & $v, \mathrm{~mm}$ & $\omega_{0 \max }, \mathrm{mm}$ & $w_{f \max }, \mathrm{mm}$ & $P_{0}, \mathrm{kN}$ & $P_{f}, \mathrm{kN}$ & $P_{c r}, \mathrm{kN}$ & $W_{c r \max }, \mathrm{mm}$ & $Q_{f r}, \mathrm{kN} / \mathrm{m}$ & $\Theta_{c r}$ & $\Omega, \mathrm{m}^{3}$ \\
\hline 4 & \multirow{3}{*}{886} & \multirow{3}{*}{1380} & \multirow{3}{*}{806} & \multirow{3}{*}{1300} & 3.533 & 7.065 & 0.294 & 0.49 & 0.721 & 11.228 & 0.336 & 0.077 & \multirow{3}{*}{0.318} \\
\hline 6 & & & & & 7.11 & 23.73 & 0.706 & 1.521 & 1.834 & 30.113 & 0.634 & 0.207 & \\
\hline 8 & & & & & 14.47 & 30.94 & 1.004 & 1.815 & 2.183 & 38.413 & 1.041 & 0.263 & \\
\hline
\end{tabular}

$b$

Fig. 9. Schemes for selecting experimental points to determine effective parameters for cellular polycarbonate sheets: $a-6 \mathrm{~mm} ; b-8 \mathrm{~mm}$

Estimation parameters to determine effective characteristics of cellular polycarbonate sheets 
By applying the estimation data obtained from formula (5) and given in Table 4, we determined effective rigidity of CPS of varying thicknesses.

In addition, when employing formula (7), we determined a critical displacement of the CPS edge in a fastening node [11]:

$$
\begin{aligned}
& \Delta x_{c r}=0.25 \sqrt{36 a^{2}+16 a \pi \omega_{\text {max }}+\pi^{2} \omega_{\text {max }}^{2}}- \\
& -1.5 a-0.25 \pi \omega_{\text {max }} .
\end{aligned}
$$

The data obtained are given in Table 5 .

Table 5

Effective characteristics of cellular polycarbonate sheets to calculate structural parameters for explosion venting panels based on them

\begin{tabular}{|l|c|c|c|}
\hline \multirow{2}{*}{\begin{tabular}{c}
\multirow{2}{*}{ Effective parameter } \\
\cline { 2 - 4 }
\end{tabular}} & \multicolumn{3}{|c|}{$\begin{array}{c}\text { Thickness of cellular } \\
\text { polycarbonate sheets }\end{array}$} \\
\cline { 2 - 4 } & $4 \mathrm{~mm}$ & $6 \mathrm{~mm}$ & $8 \mathrm{~mm}$ \\
\hline Effective rigidity, $D, \mathrm{~N} \cdot \mathrm{m}$ & 301.064 & 263.595 & 215.042 \\
\hline Critical displacement, $\Delta x_{c r}, \mathrm{~mm}$ & 2.915 & 7.708 & 9.773 \\
\hline
\end{tabular}

The derived effective characteristics for CPSs could be used to devise a procedure for structural parameters of EVP based on them.

\section{Discussion of results from experimental estimation determining of effective mechanical characteristics of cellular polycarbonate sheets}

Special feature of this study is the fact that up to now there has not been any complete study on the use of CPS as an element of explosion venting panels. The task of the current work was to determine the structural parameters of EVP with CPS in order to ensure high reliability and independence of EVP opening.

The advantage of the research reported in this work is the experimental study that we conducted. In the course of our work we devised a procedure for carrying out the testing of CPS using an experimental installation, consisting of a fixing frame, a loading node, and measuring infrastructure, shown in Fig. 2, 3. The experimental CPS test method implies determining the distributed friction forces holding cellular polycarbonate sheets in the fastening nodes by a gradual application of force to the CPS mounted in the frame's fragment until the CPS edge leaves the fastening node. The magnitude of the registered effort is considered to be a magnitude of the friction force that keeps the CPS edge within fastening nodes.
Our analysis of experimental data (Table 2) has revealed that the data that were acquired from different tests of the same samples accepted similar values. This is observed both for sample deformation data and the strength indicators data when we registered the CPS edges leaving a PVC window profile's fastening node. The above testifies to high quality of the tests conducted.

The experimental-estimation method has allowed us to determine the characteristics of cellular polycarbonate sheets in order to calculate structural parameters for explosion venting panels on their base (Table 5). This makes it possible to solve the problem, set in the current work, and ensure a high level of reliability and independence of EVP opening. The devised experimental-estimation method could be used only if the deformation of a flexible enclosing element in explosion venting panels with similar design schemes remain elastic and flexible.

The data reported in the current work could be used to devise a procedure for the structural parameters of EVP and in the forecasting of enabling CPS in EVP, which is a promising area for further research.

\section{Conclusions}

1. In order to determine the effective flexibility and critical displacement, we have experimentally studied performance of the inertia-free explosion venting panels with flexible enclosures under the influence of static loads simulating the impact of dynamic loads during explosion. The result has shown that the deformation of flexible elements up until they leave the locks of the profile occurs in an elastic region, which makes it possible, when determining effective elastic characteristics for polycarbonate cellular sheets, to apply the theory of plates and shells.

2. We have devised a procedure for determining the effective flexibility and critical displacement of CPS edges, based on the conducted experimental study into displacements and corresponding pressure, applied to the CPS, by using the proposed mathematical model from the theory of elastic plates and shells. Effective flexibility and critical displacement are used as the parameters that allow the integrated description of the CPS stressed-strained state in explosion venting panels with a standard window profile as an elastic system; the devised procedure has allowed us to determine them with the help of the proposed mathematical model.

3. We have determined effective flexibility and critical displacement of CPS edges based on the acquired experimental data. For the range of CPS thickness from $4 \mathrm{~mm}$ to $8 \mathrm{~mm}$, the derived effective flexibility was from $200 \mathrm{~N} \cdot \mathrm{m}$ to $300 \mathrm{~N} \cdot \mathrm{m}$. It has been determined that the magnitude of the critical displacement of CPS edges lies between $3 \mathrm{~mm}$ and $10 \mathrm{~mm}$.

\section{References}

1. Travmatyzm na vyrobnytstvi v Ukraini: natsionalnyi profil protiahom 2009-2013 rokiv. Informatsiyno-analitychna profspilkova dopovid.

2. Khokhotva, O. I. (2010). Pro stan promyslovoi bezpeky ta okhorony pratsi. Okhorona pratsi, 12, 7-8.

3. Migalenko, K., Nuianzin, V., Zemlianskyi, A., Dominik, A., Pozdieiev, S. (2018). Development of the technique for restricting the propagation of fire in natural peat ecosystems. Eastern-European Journal of Enterprise Technologies, 1 (10 (91)), 31-37. doi: https://doi.org/10.15587/1729-4061.2018.121727 
4. Kostenko, V., Kostenko, T., Zemlianskiy, O., Maiboroda, A., Kutsenko, S. (2017). Automatization of individual anti-thermal protection of rescuers in the initial period of fire suppression. Eastern-European Journal of Enterprise Technologies, 5 (10 (89)), 4-11. doi: https://doi.org/10.15587/1729-4061.2017.109484

5. Li, J., Hao, H. (2017). Internal and external pressure prediction of vented gas explosion in large rooms by using analytical and CFD methods. Journal of Loss Prevention in the Process Industries, 49, 367-381. doi: https://doi.org/10.1016/j.jlp.2017.08.002

6. Christian, A., Chye, G. O. K. (2014). Performance of Fiber Reinforced High-strength Concrete with Steel Sandwich Composite System as Blast Mitigation Panel. Procedia Engineering, 95, 150-157. doi: https://doi.org/10.1016/j.proeng.2014.12.174

7. Draganić, H., Gazić, G., Varevac, D. (2019). Experimental investigation of design and retrofit methods for blast load mitigation A state-of-the-art review. Engineering Structures, 190, 189-209. doi: https://doi.org/10.1016/j.engstruct.2019.03.088

8. Alberdi, R., Przywara, J., Khandelwal, K. (2013). Performance evaluation of sandwich panel systems for blast mitigation. Engineering Structures, 56, 2119-2130. doi: https://doi.org/10.1016/j.engstruct.2013.08.021

9. Niollet, J. E., Yuen, S. C. K., Nurick, G. N. (2015). A Study to Assess the Use of Cylindrical Bars as Blast Barriers. International Journal of Protective Structures, 6 (2), 263-286. doi: https://doi.org/10.1260/2041-4196.6.2.263

10. Orlov, G. G. (1987). Legkosbrasyvaemye konstruktsii dlya vzryvozashchity promyshlennyh zdaniy. Moscow: Stroyizdat, 200.

11. Pozdieiev, S., Pidgoretskiy, Y., Nekora, O., Sidnei, S., Tyshchenko, O. (2018). Research of Explode Exposure at the Relief Vent System Structures with Soft Transparent Material. International Journal of Engineering \& Technology, 7 (4.3), 298. doi: https:// doi.org/10.14419/ijet.v7i4.3.19808

12. Sinha, A., Wen, J. X. (2019). A simple model for calculating peak pressure in vented explosions of hydrogen and hydrocarbons. International Journal of Hydrogen Energy, 44 (40), 22719-22732. doi: https://doi.org/10.1016/j.ijhydene.2019.02.213

13. Zhang, S., Zhang, Q. (2018). Effect of vent size on vented hydrogen-air explosion. International Journal of Hydrogen Energy, 43 (37), 17788-17799. doi: https://doi.org/10.1016/j.ijhydene.2018.07.194

14. Pang, L., Hu, Q., Zhao, J., Lv, P., Sun, S., Yang, K. (2019). Numerical study of the effects of vent opening time on hydrogen explosions. International Journal of Hydrogen Energy, 44 (29), 15689-15701. doi: https://doi.org/10.1016/j.ijhydene.2019.04.175

15. Feldgun, V. R., Yankelevsky, D. Z., Karinski, Y. S. (2016). A nonlinear SDOF model for blast response simulation of elastic thin rectangular plates. International Journal of Impact Engineering, 88, 172-188. doi: https://doi.org/10.1016/j.ijimpeng.2015.09.001 